\title{
SURFACE MODIFICATION OF TEMPO-MEDIATED CELLULOSE NANOFIBRIL WITH OCTADECYLAMINE
}

\author{
Nanang Masruchin ${ }^{1}$, Arif Nuryawan ${ }^{2}$, Wida Banar Kusumaningrum ${ }^{1}$, Sudarmanto ${ }^{1}$, \\ Lilik Astari ${ }^{1}$, Putri Amanda ${ }^{1}$, Resti Marlina ${ }^{1}$ and Lisman Suryanegara ${ }^{1}$ \\ ${ }^{1}$ Research Center for Biomaterials, Indonesian Institute of Sciences \\ Jl. Raya Bogor KM 46 Cibinong, Jawa Barat 16911 \\ ${ }^{2}$ Department of Forest Products Technology, Faculty of Forestry \\ Jl. Tri Dharma Ujung No.1 Kampus USU, Medan, North Sumatera, 20155 \\ E-mail: masruchin@biomaterial.lipi.go.id
}

Received: 00 April 2019 Revised: 00 June $2019 \quad$ Accepted: 00 June 2019

\begin{abstract}
SURFACE MODIFICATION OF TEMPO-MEDIATED CELLULOSE NANOFIBRIL WITH OCTADECYLAMINE. In this study, surface modification of 2,2,6,6-tetramethylpiperidine-1-oxyl radical TEMPO-cellulose nanofibrils (TCNF) was obtained by 1-ethyl-3-(3-dimethylaminopropyl) carbodiimide hydrochloride (EDC) and N-hydroxysuccinimide (NHS)-mediated system. The carboxylate groups on TCNF surface was replaced by conjugation of octadecylamine (ODA). The conversion of the carboxylate groups on CNF into amide I and II groups was confirmed by attenuated transform reflectance-infrared (ATR-FTIR) and elemental analysis study. Further, decarboxylation of TCNF at higher temperature was hindered by the presence of amide groups resulted in the higher thermal stability of TCNF as observed by thermogravimetry analysis (TGA). These results suggested the possibility of modifying surface negatively charged of TCNF with conjugated amine groups into thermally stable nanocellulose.
\end{abstract}

Keywords: Cellulose nanofibril, TEMPO, Octadecylamine, Conjugation, Thermal stability

\begin{abstract}
ABSTRAK
MODIFIKASI NANOSEULOSA DARI PROSES OKSIDASI TEMPO DENGAN OCTADECYLAMINE. Penelitian ini membahas proses modifikasi permukaan dari nanoselulosa (TCNF) yang di peroleh dari pulp hardwood proses kraft yang terputihkan dengan proses oksidasi menggunakan 2,2,6,6-tetramethylpiperidine-1-oxyl radical (TEMPO). Nanoselulosa yang dihasilkan memiliki muatan dengan terbentuknya gugus karboksil $\left(-\mathrm{COO}-\mathrm{Na}^{+}\right)$sehingga membuat nanoselulosa semakin bersifat hidrofilik. Modifikasi ini ditujukan untuk mensubstitusi gugus karboksil dengan octadecylamine. Reaksi dijalankan dengan sistem 1-ethyl-3-(3-dimethylaminopropyl) carbodiimide hydrochloride (EDC) dan penambahan N-hydroxysuccinimide (NHS). Dari hasil analisa spektroskopi sinar infra (ATR-FTIR) diketahui bahwa gugus karboksil terkoversi menjadi gugus amide I dan amide II, selain itu data dari thermogramitry analysis (TGA) menunjukkan peningkatan stabilitas panas dari TCNF. Dari percobaan ini dapat disimpulkan bahwa modifikasi nanoselulosa dapat dilakukan dengan substitusi gugus aktif sehingga meningkatkan kestabilan panas nanoselulosa dan diharapkan dapat memperluas aplikasi nanoselulosa dalam bidang nanokomposit.
\end{abstract}

Kata kunci: Nanoselulosa, TEMPO, Octadecylamine, Konjugasi, Stabilitas panas

\section{INTRODUCTION}

TEMPO-cellulose nanofibril (TCNF) obtained by 2,2,6,6-tetramethylpiperidine-1-oxyl radical (TEMPO)mediated oxidation has gained popularity in the field of bio-nanomaterials applications [1-7], due to the regioselective surface modification of cellulose which promote large amounts of anionically charged sodium carboxylate that may cause the individualization of cellulose microfibrils by electrostatic repulsion and/or 
osmotic effects in water, therefore reducing the energy consumption for nanocellulose isolation. Isogai et al. (2011) [8] reported the required energy was below $7 \mathrm{MJ} . \mathrm{Kg}^{-1}$ of cellulose with yield above than $90 \%$. In addition, the oxidation system can be conducted in environmentally-benign conditions (aqueous, $\mathrm{pH}$ 10-11, room temperature and atmospheric pressure). Thus suggested that TEMPO oxidation process is favorable for commercialization of nanocellulose production. Although TEMPO oxidant is expensive, however, co-oxidant reagents such as $\mathrm{NaClO}$ or $\mathrm{NaClO}_{2}$ are inexpensive. Mao et al. (2010) [9] reported that the expensive TEMPO can be recycled and reused with reinforced addition back of sodium hypochlorite into the system and thus remained still effective in generating carboxylic acid groups.

The oxidation of cellulose occured only on the surface of cellulose, keeping the inside crystal structure unoxidized $[10,11]$ and maintaining the crystallinity, the modulus of elasticity of oxidized cellulose unchanged. However, the presence of carboxylated groups decreased the thermal stability of oxidized cellulose. Thus will limit the application of cellulose nanofibril especially for polymer nanocomposite. Fukuzumi et al. (2010)[12] modified the carboxylate cellulose by counter ion using several cation such as $\mathrm{CaCl}_{2}, \mathrm{Ca}(\mathrm{OAc})_{2}, \mathrm{Ca}\left(\mathrm{NO}_{3}\right)_{2}$ and $\mathrm{CaI}_{2}$ Instead of ionic interaction, here we reported covalent bonded modification of TEMPO-oxidatized cellulose with converted the carboxyl groups into octadecylamine. The aim of this study was to characterized the conjugation of octadecylamine groups onto cellulose nanofibrils by analyzing the functional groups, the elemental analysis and the crystal structure using X-ray diffraction and observed the thermal degradation of modified TCNF.

Later on, the obtained modified cellulose nanofibrils could be used as reinforcing agent as well as improving dispersibility of cellulose in biocomposite production for high toughness composite [13].

\section{MATERIAL AND METHODS}

\section{Materials and Instruments}

TCNF was isolated from dried hardwood bleached kraft pulp (HW-BKP) sheet (Moorim Paper Co. Ltd., Korea) which stored in a humidity chamber (JSR, LowTempIncubator, JSBL-250C, Korea) at $25^{\circ} \mathrm{C}$ before used. The materials used were as follows: TEMPO $\left(\mathrm{C}_{9} \mathrm{H}_{18} \mathrm{NO}, 99 \%\right.$, Sigma-Aldrich), sodium bromide (NaBr, Sigma-Aldrich), sodium hypochlorite solution with chlorine content $12 \%$ ( $\mathrm{NaClO}$, Sigma-Aldrich), 1-ethyl-3-(3-dimethylaminopropyl) carbodiimide hydrochloride (EDC $>98 \%$ purity, Sigma-Aldrich), octadecylamine (ODA 99.8\%, Sigma-Aldrich), $\mathrm{N}$-hydroxysuccinimide (NHS $>98 \%$ purity, SigmaAldrich), dimethylformamide (DMF, ACS reagent grade
99.8\%, Sigma-Aldrich). Water for this experiments was purified using Ultrs-pure (ROtech, Korea) with conductivity around $6 \mu \mathrm{S} / \mathrm{cm}$.

\section{TCNF isolation}

Isolation of TCNF was conducted following a previously published procedure[5]. In brief, $2 \mathrm{~g}$ of HWBKP was diluted in a water suspension containing $0.025 \mathrm{~g}$ TEMPO and $0.25 \mathrm{~g} \mathrm{NaBr}$. The mixture temperature was maintained at $23{ }^{\circ} \mathrm{C}$. The oxidation reaction was started by adding $\mathrm{NaClO}$ as the oxidant reagent, 7.85 $\mathrm{mmol} / \mathrm{g}$, drop wise in order to keep the $\mathrm{pH}$ below 10 during the addition. Throughout the reaction process, the $\mathrm{pH}$ was adjusted at by adding $0.5 \mathrm{~N} \mathrm{NaOH}$ at 10.5 . When the $\mathrm{pH}$ reached constantly at 10.5 , there was no $\mathrm{NaOH}$ was needed, indicating that the reaction finished. The excess $\mathrm{NaClO}$ was quenched by adding ethanol (ca. $5 \mathrm{~mL}$ ). After that, the $\mathrm{pH}$ of the solution was neutralized by $0.5 \mathrm{~N} \mathrm{HCl}$. The TEMPO-oxidized pulp slurry was filtered, and washed several times. And then, $2 \%$ wt slurry of TEMPO-oxidized pulp was subjected to ultrasonication treatment (Sonomasher, power 30\%, frequency $20,320 \mathrm{~Hz}$ ). Finally, by centrifugation $(12,000 \mathrm{~g})$ (Labogene 1580, Centrifuge, Gyrozen Co., Ltd., Daejeon, Korea), the TCNF was obtained from the supernatant, where un-fibrillated fibers were separated in sediment.

\section{Conductometric Titration}

The carboxyl content of TCNF was measured by the conductometric titration method [6]. The $80 \mathrm{~mL}$ cellulose suspension with $0.05 \%$ solid content was stirred continually with addition of $5 \mathrm{~mL} 0.01 \mathrm{M} \mathrm{NaCl}$ while the $\mathrm{pH}$ of the suspension was adjusted to 2.5-3 by addition of $0.1 \mathrm{M} \mathrm{HCl}$. The agglomeration of TCNF was hindered by making the suspension in very low solid content. The titration was started by adding 0.01 $\mathrm{M} \mathrm{NaOH}$ was added at a rate of $0.1 \mathrm{~mL} / \mathrm{min}$ up to $\mathrm{pH} 11$ while the conductivity changes was recorded manually using a conductometer (SevenGo, METTLER TOLEDO,

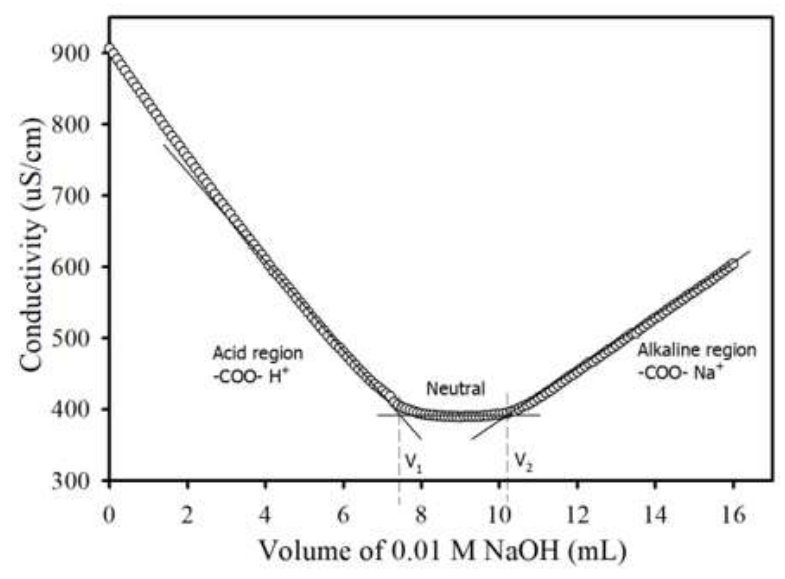

Figure 1. Typical graph for conductometric titration 
China). A typical graph for the conductometric titration is shown in Figure 1. The conductivity decreased until the acid was neutralized by the addition of $\mathrm{NaOH}$. At the end of neutralization $\left(V_{l}\right)$, the conductivity remained unchanged to the end of step $\left(V_{2}\right)$. Further addition of $\mathrm{NaOH}$ increased the conductivity.

\section{Octadecylamine Conjugation Onto TCNF (Amidated CNF)}

TCNF suspension $(1000 \mathrm{~mL}$ of $0.5 \mathrm{wt} \%$, $1.6 \mathrm{mmol} / \mathrm{g}$ COONa content) was transferred into a three-neck round bottom flask with overhead stirring (400-500 rpm) and then the flask was equilibrated at $50{ }^{\circ} \mathrm{C}$ in water bath. EDC (7.76 g, $\left.40.5 \mathrm{mmol}\right)$ and NHS $(5.59 \mathrm{~g}, 48.6 \mathrm{mmol})$ were dissolved in $20 \mathrm{~mL}$ water and added into the TCNF suspension. The $\mathrm{pH}$ of the reaction mixture was adjusted to $5.5-6.0$ and maintained for $30 \mathrm{~min}$ to complete the activation of TCNF surface carboxylate groups. The solution of ODA (8.7 g, 32.4 $\mathrm{mmol})$ in DMF $(250 \mathrm{~mL})$ was added to the TCNF suspension, which instantly changed the appearance from transparent to white. The $\mathrm{pH}$ of the mixture was subsequently adjusted and maintained at 7.5-8.0 using

Step 1

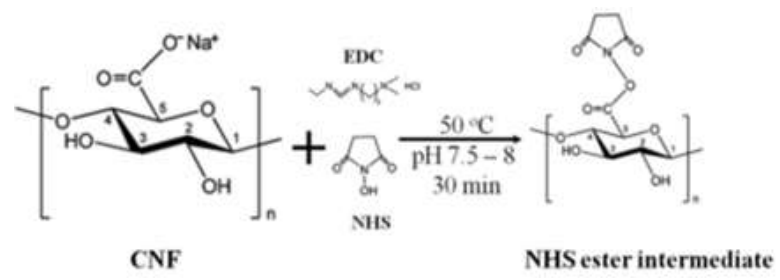

Step 2

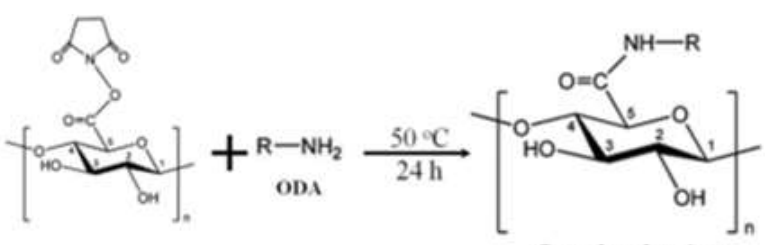

NHS ester intermediate

Octadecylamin conjugated CNF

Figure 2. Reaction scheme of conjugating octadecylamine into TCNF

$\mathrm{HCl}(1 \mathrm{~N})$ and $\mathrm{NaOH}(0.5 \mathrm{~N})$. The stirring was continued for $24 \mathrm{~h}$ until the suspension turned into slightly yellow.

After the reaction finished, ODA-treated TCNF were recovered by dialysis and centrifugation. First, the suspensions were centrifuged to separate the nanocellulose (residue) from the mixture of solvents and dissolved reagents (supernatant). The residues were twice dispersed and centrifuged in water to remove traces of remaining reagents. Further, additional washes were performed with $\mathrm{HCl}(0.1 \mathrm{~N})$ and ethanol respectively, to regenerate any residual carboxyl remaining after the treatments and to extract any remaining traces of unbound ODA. These steps were followed by multiple water washes until $\mathrm{pH}$ was neutral. The reaction scheme of this research is presented in Figure 2. The carboxylated groups on C6 was converted into octadecylamine by intermediate ester formation.

\section{Characterizations}

\section{Morphology of TEMPO-oxidized Cellulose Nanofibrils}

Morphology of cellulose nanofibrils was observed under TEM (H-7600, Hitachi) performed at an accelerating voltage of $100 \mathrm{kV}$. Sample was prepared using following method; a very low concentration of TCNF suspension about $0.005 \% \mathrm{w} / \mathrm{v}$ was homogenized. A drop of the suspension was put on plastic film then copper grid was dipped in the suspension about 15 second, after that grid with nanocellulose on it was dipped in a drop uranyl acetate $2 \%$ aqueous on plastic film about 15 seconds. Excessed solution was blotted using filter paper. The grid was ready for examination after it was dry.

\section{ATR-FTIR Analysis}

Modified TCNF were freeze-dried (Ilshin BioBase Co. Ltd, FDA8508, Korea). Then, were grounded and analyzed using ALPHA-P model attenuated total reflectance-infrared (ATR-IR) equipment (Bruker Optics, Germany). Absorption in the range $4000-400 \mathrm{~cm}^{-1}$ was measured as the average value of 25 scans at $4 \mathrm{~cm}^{-1}$ resolution. The measurement was conducted in two replications.

\section{ElementalAnalysis}

The $\mathrm{C}, \mathrm{H}$ and $\mathrm{N}$ content on cellulose before and after treatment was determined by elemental analysis (Flash 2000; Thermo Fischer Scientific Inc., United States)

\section{X-Ray Difractometer}

XRD measurements were carried out with an X-ray diffractometer (D/Max-2500, Rigaku, Japan) with $\mathrm{CuK} \alpha-1 \mathrm{X}$-ray source with a wavelength of $1.541 \AA$ from $10^{\circ}$ to $40^{\circ}$ in reflection mode, with steps of $0.02^{\circ}$ and at a scanning rate of $6 \% \mathrm{~min}$.

\section{Thermogravimetry Analysis (TGA)}

Thermogravimetry (TG) and and derivative thermogravimetry (DTG) analysis were carried out using a thermogravimetry instrument (TGA Q500 V20.13, Korea). About $10 \mathrm{mg}$ of dried powder samples were heated up at a heating rate of $10^{\circ} \mathrm{C} / \mathrm{min}$. from 25 to $600^{\circ} \mathrm{C}$ under nitrogen atmosphere. 


\section{RESULT AND DISCUSSIONS}

\section{Carboxyl Content of TCNF}

The carboxyl content of cellulose obtained for this study was about $1.4 \mathrm{mmol} / \mathrm{g}$. In other words the degree of substitution of hydroxyl groups were 0.23 which indicated that in every 4.4 anhydroglucose unit (AGU, monomer) there was 1 carboxylate group. The higher co-oxidant level, the more carboxyl content on the cellulose surface [5]. However, it costs on the decrease of cellulose degree of polymerization [14].

The reaction with octadecylamine involved EDC/ NHS process which made the surface of CNF became slightly hydrophobic by converting the carboxyl groups with amide (Amidation). Thus treatment was necessary since the high concentration of surface carboxyl group makes TEMPO-CNF strongly hydrophilic, i.e., water retention values of $400 \%$ and $200 \%$ for the salt form ($\mathrm{COO}-\mathrm{Na}+)$ and free acid (-COOH) forms, respectively[14]. Which further limit the application of the CNF in non polar solvent or hydrophobic polymer composite. Herewith the characterizations of CNF after amidation process:

\section{Morphology of TEMPO-CNF}

The morphology of cellulose nanofibrils is presented in Figure 3. Instead of cellulose nanocrystal

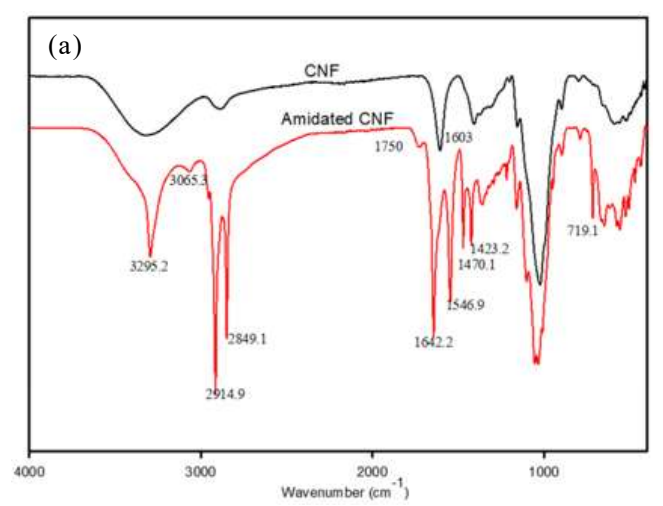

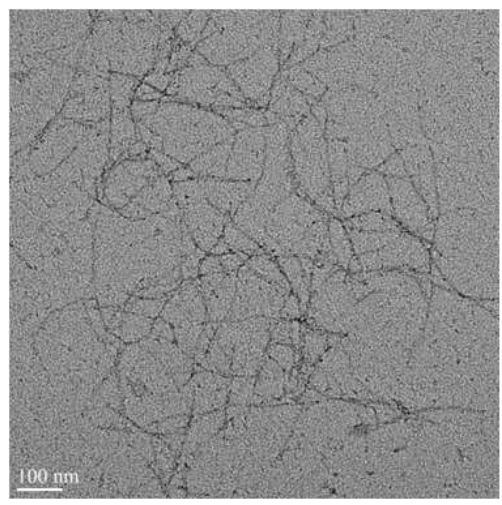

Figure 3. TEM image of TCNF

that was obtained from harsh acid hydrolysis which remained only the crystal part region, cellulose nanofibrils are a combination of amorphous and crystalline region of cellulose fibrils [15]. Figure 3 shows that cellulose nanofibrils have long entagled fibrils up to micron in length while the diameter was below than $10 \mathrm{~nm}$ [16]. Unfortunately, we did not have the picture of modified amidated cellulose nanofibril. The color of freeze dried modified CNF changed from white into light yellow. After freeze dried processing, the modified TCNF agglomerated into powdered form, which indicated the formation of hydrogen bonding among hidroxyl groups from unreacted sites. We had tried to redisperse the dried modifed TCNF into water solution, however due to the

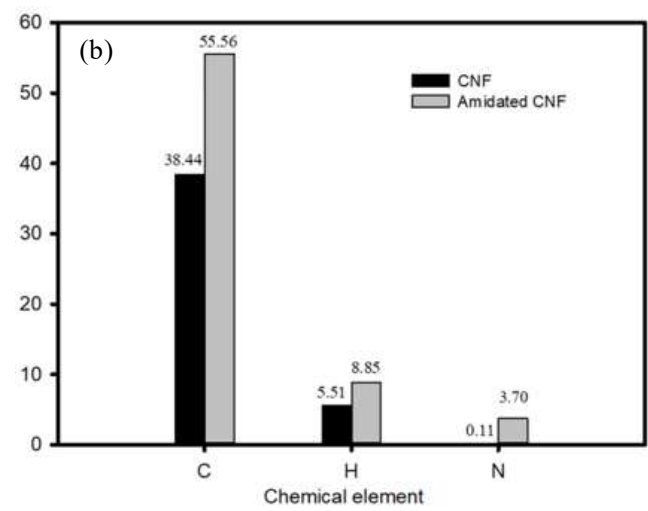

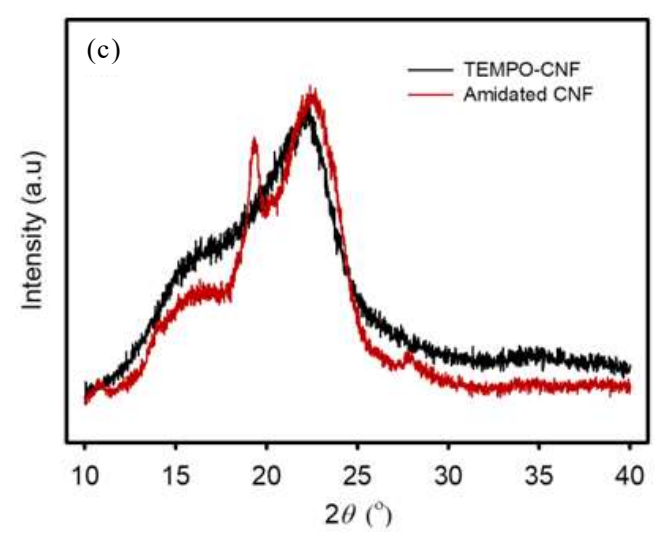

Figure 4. (a). ATR-FTIR spectra, (b). elemental analysis and c. XRD diffractogram of CNF and amidated CNF 
conjugated of octadecylamine, TCNF were not diluted well, suggesting that the modified TCNF improved its hydrophibicity.

\section{ATR-FTIR Analysis}

ATR-FTIR spectra (Figure $4 \mathrm{a}$ ) confirms the presence of amide $\mathrm{I}\left(\mathrm{C}=\mathrm{O}\right.$ stretching, $\left.1642 \mathrm{~cm}^{-1}\right)$ and amide II (combined N-H deformation and C-N stretching, 1546 $\mathrm{cm}^{-1}$ ) bands on the TCNF after amidation process. Whereas the peak at $1603 \mathrm{~cm}^{-1}$ (asymmetric $\mathrm{C}=\mathrm{O}$ stretching vibration of the COO-groups) from TCNF was reduced indicates complete consumption of available -COONa groups during the amidation. Peak at $3295 \mathrm{~cm}^{-1}$ represents $\mathrm{N}-\mathrm{H}$ stretching vibration of secondary amides, peak $2849-2915 \mathrm{~cm}^{-1}$ corresponds to - $\mathrm{CH}$ methyl and methylene stretching and deformation at $\left(1470 \mathrm{~cm}^{-1} / 719 \mathrm{~cm}^{-1}\right)$ bands showed the octadecyl tail were observed in the spectrum of amidated TCNF [17]. Another interesting finding is the observation of elemental component of modified TCNF.

Figure $4 \mathrm{~b}$ shows nitrogen content increased after amidation process as well as $\mathrm{C}$ and $\mathrm{H}$ content, as evident of octadecylamine presented on the surface of TCNF. The XRD diffraction profiles of amidated TCNF, together with those of oxidized CNF reference are presented in Figure $4 \mathrm{c}$. After the crystallinity analysis, the crystallinity of CNF before and after amidation process was not changed significantly, with the exception of strong and narrow peak after amidation at $19^{\circ}$ that correspond to crystalline impurity presented in our sample. These patterns is also reported in the literature [18]. Thus result suggested that the amidation process did not modify the morphology and the core of cellulose nanofibrils since the substitution took place only on the surface of cellulose.

\section{Thermogravimetry analysis}

Figure 5 depicts the profile of weight loss (Figure 5a) and derivative weight loss (Figure 5b) of amidated CNF. Thermal degradation of cellulose involves a groups of endothermic reactions that can occur in the form of dehydration, hydrolysis, oxidation, decarboxylation especially for oxidated cellulose and transglycosylation process [19].

From figure $5 \mathrm{a}$, it shows clearly that the dehydration process was higher in unmodified CNF, suggested that water affinity of amidated CNF decreases (the amidated CNF was more hydrophobic). Further, in case of TEMPO-mediated CNF, the formation of sodium carboxylate groups leads to a significant decrease in thermal degradation point due to decarboxylation mechanism. The first step of mass loss is a fast degradation starts at $220-274^{\circ} \mathrm{C}$ and followed by slow degradation at $450^{\circ} \mathrm{C}$ (Figure $5 \mathrm{~b}$ ). It is generally accepted that the first step in the cellulose pyrolysis is mainly due to the depolymerization of solid cellulose to form levoglucosan, while the second step of mass loss of TEMPO-CNF is due to the lower thermal stability of uronic acids such as glucuronic and galacturonic acid [12]. In case of amidated CNF, decarboxylation of TEMPO-CNF was hindered by the presence of amide groups resulted in higher thermal stability. Fukuzumi et al. 2010 [12] studied to improve thermal stability of TEMPO-CNF by modification of carboxyl groups with counter ion-exchanged and methyl esterification (trimethylsilyl diazomethane). These metylated increased the degradation temperature from 273 to $313^{\circ} \mathrm{C}$. In this study, maximum degradation showed at 309.2 and 383.1 ${ }^{\circ} \mathrm{C}$, while the char residue at $600{ }^{\circ} \mathrm{C}$, the amidated TCNF resulted in lower residue. This result are in conjunction with the thermal stability study of oxidized bacterial cellulose compared to unmodified counterpart [20].

\section{CONCLUSION}

A method to improved thermal stability of cellulose nanofibril by covalent bonding has been obtained by conjugation of octadecylamine onto TEMPO-mediated cellulose nanofibrils. The hidrophobicity of cellulose also improved due to the
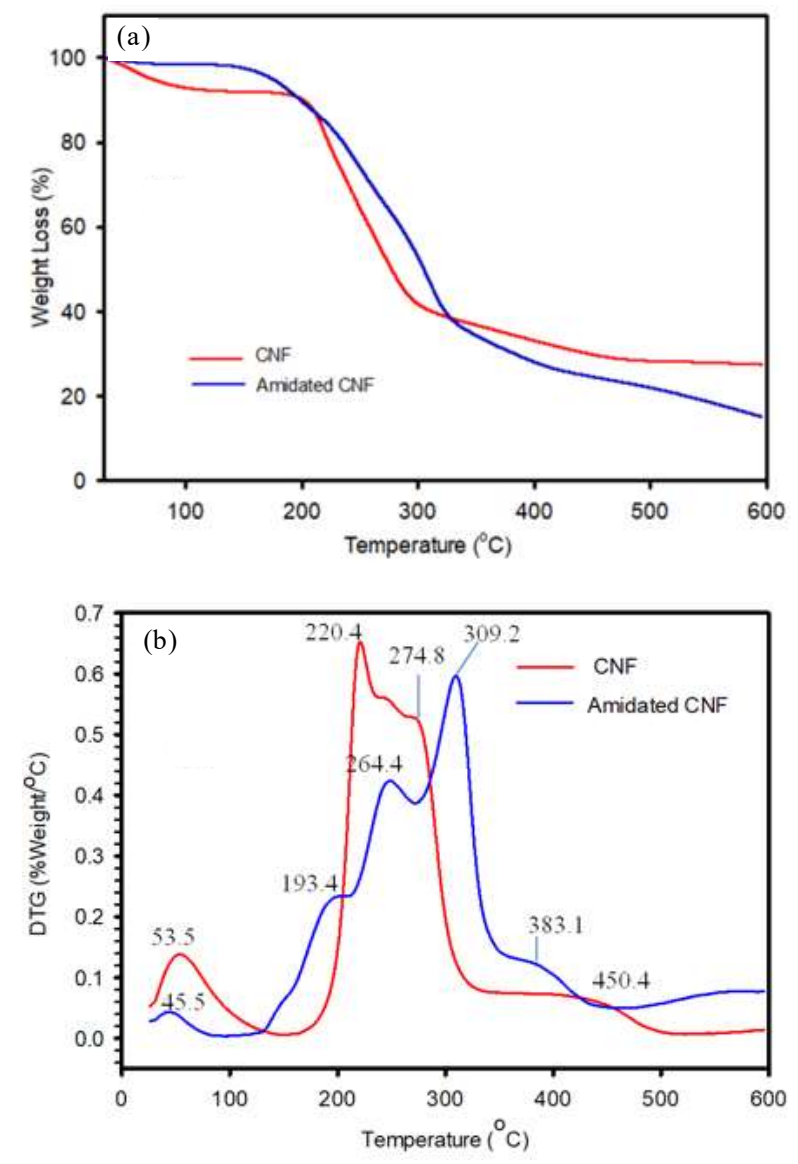

Figure 5. (a). Thermogravimetry weight loss and (b). derivative thermogravimetry weight loss of CNF and amidated CNF plots as a function of temperature. 
converted of carboxyl groups into amide groups. The dispersion of modified cellulose in non polar solvent will be studied further.

\section{ACKNOWLEDGMENTS}

The authors wish to thank to Priotitas Bidang Program DIPA 2019 and INSINAS KemenristekDikti Program 2019 for supporting this research. Muhammad Adly Rahandi Lubis for analyzing the elemental analysis measurement.

\section{REFERENCES}

[1].. E. Syafri, A. kasim, H. Abral, A. Asben, Sudirman." Pembuatan dan Karaterisasi Komposit Bioplastik Berbasis Filler Cellulose Micro Fibers Rami”. J. Sains Materi Indonesia, vol. 19, pp. 66-71, 2018.

[2]. D. Klemm, E.D. Cranston, D. Fischer, M. Gama, S.A. Kedzior, D. Kralisch, F.. Kramer, T. Kondo, T. Lindstorm, S. Nietzsche, K. Petzold-Welcke, F. Rauchfub."Nanocellulose as a natural source for groundbreaking applications in materials science: Today's state". Mater. Today, vol. 21, pp. 720-748, 2018.

[3]. M.A. Mohamed, M.A. Mutalib, Z.A.M. Hir, M.F.M. Zain, A.B. Mohamad, L.J. Minggu, N.A. Awang, W.N.W. Salleh.”An Overview on cellulose-based material in tailoring bio-hybrid nanostructured photocatalysts for water treatment and renewable energy applications". Inter. J. Biological Macromol., vol. 103,pp. 1232-1256, 2017.

[4]. O. Necyporchuk, M.N. Belgacem, J. Bras."Production of cellulose nanofibrils: A review of recent advances". Ind. Crops and Prod., vol. 93, pp. 2-25, 2016.

[5]. N. Masruchin, , B-D. Park.'Manipulation of surface carboxyl content on TEMPO-oxidized cellulose fibrils. J of Korean Wood Science and Technol., vol. 43, pp.613-627, 2015a.

[6]. N. Masruchin, B-D. Park, V. Causin.'Influence of sonication treatment on supramolecular cellulose microfibril-based hydrogels induced by ionic interaction". J of Industrial Eng. and Chem., vol. 29, pp. 265-272, 2015 b.

[7]. N. Masruchin, B-D. Park, J.M. Lee. "Surface modification of TEMPO-oxidized cellulose nanofibrils for composites to give color change in response to $\mathrm{pH}$ level". Cellulose, vol.25, pp. 70797090, 2018.

[8]. A. Isogai, T. Saito, H. Fukuzumi." TEMPO-oxidized cellulose nanofibers". Nanoscale 3: 71-85, 2011.
[9]. L. Mao, P. Ma, K. Law, C. Daneault, F. Brouillette."Studies on Kinetics and Reuse of Spent Liquor in the TEMPO-Mediated Selective Oxidation of Mechanical Pulp". Ind. Eng. Chem. Res., vol. 49, pp. 113-116, 2010.

[10]. Y. Okita, T. Saito, A. Isogai. "Entire Surface Oxidation of Various Cellulose Microfibrils by TEMPO-Mediated Oxidation". Biomacromolecules, vol. 11, pp. 1696-1700, 2010.

[11]. D.O. Carlsson, J. Lindh, L. Nyholm, M. Stromme, A. Mihranyan.”Cooxidant-free TEMPO-mediated oxidation of highly crystalline nanocellulose in water". RSC Adv., vol. 4, pp. 52289-52298, 2014.

[12]. H. Fukuzumi, T. Saito, Y. Okita, A. Isogai. "Thermal stabilization of TEMPO-oxidized cellulose. Polym. Degrad. and Stab., vol. 95, pp. 1502-1508, 2010.

[13]. Subyakto, E. Hermiati, N. Masruchin, Ismadi, K.W. Prasetiyo, W.B. Kusumaningrum and B. Subiyanto. "Injection molded of bio-micro-composite from natural fibers and polylactic acid. Wood Research Journal, vol. 2, pp, 21-26, 2011.

[14]. T. Saito, S. Kimura, Y. Nishiyama, A. Isogai. "Cellulose Nanofibers Prepared by TEMPOMediated Oxidation of Native Cellulose". Biomacromolecules, vol. 8, pp. 2485-2491, 2007.

[15]. D. Bhattacharya, L.T. Germinario, W.T. Winter. "Isolation, preparation and characterization of cellulosic microfibers obtained from bagasse". Carbohydr Polym, vol. 73, pp. 371-377, 2008.

[16]. B-D. Park, I.C. Um, S-Y. Lee, A. Dufresne."Preparation and Characterization of Cellulose Nanofibril/Polyvinyl Alcohol Composite Nanofibers by Electrospinning". J. Korean Wood Sci. Technol, vol 42, pp. 119-129, 2014.

[17]. R.K. Johnson, A. Zink-Sharp, W.G. Glasser. “ Preparation and characterization of hydrophobic derivatives of TEMPO-oxidized nanocellulose. Cellulose, vol. 18, pp. 1599-1609, 2011.

[18]. N. Follain, M.F. Marais, S. Montanari, M.R. Vignon."Coupling onto surface carboxylated cellulose nanocrystals". Polymer, vol. 51, pp. 53325344, 2010.

[19]. F. N. Gómez, M. Y. Combariza, C. Blanco-Tirado. "Facile cellulose nanofibrils amidation using a 'one-pot' approach". Cellulose, vol. 24, pp. 717730, 2017.

[20]. E.S. do Nascimento, A.L.S. Pereira, M. de Oliveira Barros, M.K. de Aaraujo Barroso, H.L.S. Lima, M. de Fatima Borges, J.P. de Andrade Feitosa, H.M.C de Azeredo, M. de Freitas Rosa. "TEMPO oxidation and high-speed blending as a combined approach to disassemble bacterial cellulose". Cellulose, inpress, https://doi.org/10.1007/s10570-018-2208-2, 2019. 